\title{
Spectrophotometric Determination Of Vanadium (V) With Schiff Base Derived From Pyridine-2- Carboxaldehyde And 2-Amino Pyridine By Preliminary Adsorption On Polyurethane Foam
}

\author{
Jyoti Sharma*, Sunita (Soni) Tondon*, Nidhi Agarwal ${ }^{\text {*** }}$ \\ * Associate Professor, Department of Chemistry, Raj Rishi Govt. (PG) College, Alwar, 301001 \\ *** Research Scholar, Raj Rishi Bhartrihari Matsya University, Alwar(Raj.), India \\ DOI: 10.29322/IJSRP.10.10.2020.p10668 \\ http://dx.doi.org/10.29322/IJSRP.10.10.2020.p10668
}

\begin{abstract}
The spectrophotometric determination of Vanadium (V) by adsorption of its pyridine-2-carboxaldehyde and 2amino pyridine complex after adsorption on polyurethane foam is described. The complex is eluted from the foam with chloroform and absorbance is measured at $400 \mathrm{~nm}$. Beer's law is obeyed in the concentration range 5-90 $\mu \mathrm{g}$ of vanadium. The molar absorptivity was found to be $2.3108 \mathrm{x}$ $10^{4} \mathrm{Lmol}^{-1} \mathrm{~cm}^{-1}$ and sensitivity being $1.14 \times 10^{-2} \mu \mathrm{g} \mathrm{cm}^{-2}$ for the absorbance of 0.001 . The effect of various parameters namely $\mathrm{pH}$, reagent, adsorbant, shaking time and diverse ions have also been investigated.
\end{abstract}

Index Terms- Polyurethane foam, Schiff base, Spectrophotometric determination, Vanadium,

\section{INTRODUCTION}

B iological activities of Schiff bases are very well known. Some of them also show anticarcinogenic properties ${ }^{\mathbf{1 - 2}}$. Schiff bases can be obtained from different amines and carbonyl compounds. These Schiff bases can form chelate complexes with different metal ions. These shiff bases contain $-\mathrm{C}=\mathrm{N}$ - imine linkage which is responsible for their biological activity and produce colour with metal ions by the formation of complex ${ }^{3-4}$. The following Schiff bases have been synthesized by respective carbonyl compound and amine in-

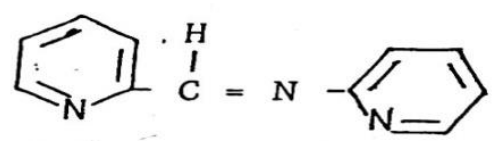

Figure. 1: SB derived from pyridine-2-carboxaldehyde and 2-amino pyridine.

Usually many organic compounds are used in analytical chemistry. Ample of investigation has been done for the development of new analytical organic reagents ${ }^{5-10}$. Due to the environmental contamination with vanadium in recent years it is the area of interest of chemists. This metal is widely involved in the enzymetic reactions and nitrogen fixation. ${ }^{\mathbf{1 1}}$ It is a part of essential micronutrient in organisms which is responsible for health and disease.

Determination of vanadium is not easy from analytical point of view due to presence of interfering ions like iron(III). Hydroxyquinoline used for the determination of vanadium in bio samples has lack of selectivity and its $\mathrm{pH}$ range is not wide. ${ }^{\mathbf{1 2}}$ After this many reagents have been used for the determination of vanadium like reagent made by hydrogen peroxide, $\alpha$-benzoinoxime and diaminobenzidine, Schiff base derived from 2-furfural-dehyde and paminophenyl mercaptoacetic acid and one more Schiff base derived from ethylenediamine and 4-benzoyl-1-phenyl-3methyl-2-pyrazidine-5-one. ${ }^{13-15}$

Above mentioned Schiff bases are valuable towards transition metal ions. In this series new Schiff base derived from pyridine-2-carboxaldehyde and 2-amino pyridine has interesting analytical application. ${ }^{\mathbf{1 6}}$ First row transition metals Vanadium (V) forms a stable water insoluble chelate complex with Schiff base derived from pyridine - 2 carboxaldehyde and 2- amino pyridine. A new "Solid Liquid Extraction" technique is used for the absorption of metal chelate on polyurethane foam.

\section{MATERIALS AND APPARATUS}

Various materials and arrangements were utilized in the spectrophotometric assurance:

A. SCHIFF BASE :-

Schiff was acquired from pyridine -2 - carboxaldehyde and 2 - amino pyridine. Ethanolic arrangement of carbonyl compound pyridine-2-carboxaldehyde was blended in with 2amino pyridine in ethanol in 1:1 molar proportion, refluxed over water shower for 3-5 hours. The subsequent Schiff base was isolated out . Blend was cooled, washed, dried in air and recrystallised by ethanol. Espresso earthy colored hued precious stones were acquired.

\section{B. STANDARD METAL ION SOLUTION:-}

A standard stock arrangement of vanadium (V) (1000ppm) was set up by dissolving sufficient measure of ammonium meta 
vendate in refined water. Weakened arrangements of different focus were set up by weakening of this stock arrangement.

\section{BUFFER SOLUTION:-}

Two cushion arrangements of $\mathrm{pH}$ run 3-6 and 8-11 are set up by blending explicit measure of $1 \mathrm{M}$ acidic corrosive and $1 \mathrm{M}$ ammonium acetic acid derivation arrangement and $1 \mathrm{M}$ fluid smelling salts and $1 \mathrm{M}$ ammonium acetic acid derivation arrangement individually.

\section{REAGENT SOLUTION:-}

It was set up by dissolving $0.2 \mathrm{gm}$ of Schiff base compound in $100 \mathrm{ml}$ ethanol.

\section{E. POLYURETHANE FOAM :-}

It was set up by the strategy for Hamon et al. ${ }^{17}$ Polyurethane froth pieces were cut in $1 \mathrm{~cm} 3$ size from a froth cushion which was gotten from a neighborhood departmental store . All froth pieces were cleaned by good cleaning strategies which were assessed previously. Right off the bat, the froth was more than once pressed in an enormous amount of $1 \mathrm{M}$ hydrochloric corrosive for certain minutes to a few hours to expel potential contaminants and afterward washed with refined water. They were next liberated from corrosive by crushing in water. Air dried in open at room temperature. No significant changes in polymeric properties because of these treatment was watched. Along these lines, perception uncovered that 1 hour pressing was sufficient. Chow et $\mathrm{al}^{\mathbf{1 7}}$ recommended that the froth pieces ought to be as uniform as could be expected under the circumstances.

\section{F. APPARATUS:-}

Spectrophotometer EC model (GS - 5701) was used for the spectrometric estimations. Systronics model (Sr. No. 5244) was used for $\mathrm{pH}$ estimations.

\section{PROCEDURE}

A fraction $(1.0 \mathrm{ml})$ of standard vanadium(V) solution containing $15-90 \mu \mathrm{g}$ of vanadium was taken in a beaker and $2.5 \mathrm{ml}$ of $0.2 \%$ Schiff base solution was added to it. The $\mathrm{pH}$ was ranged for 3.0. After making volume $10 \mathrm{ml}$ it was allowed to rest for $2 \mathrm{~min}$ for complete development of colour. Then, seven polyurethane pieces were added to this solution. ${ }^{18}$ The flask was shaken for 60 seconds to allow the metal complex formed to be adsorbed on the foam. The foam pieces then squeezed with a glass plunger. These foam pieces which contain vanadium ion complex were transferred to glass beaker. The complex was rinsed from the foam pieces by squeezing with two portion of $2.5 \mathrm{ml}$ chloroform. To remove traces of water $2.0 \mathrm{gm}$ anhydrous sodium sulphate was added. Absorbance was measured in the region of $370-560 \mathrm{~nm}$ wave length. Calibration curve was constructed under similar conditions.

\section{RESULT AND DISCUSSION}

\section{A. ABSORPTION SPECTRA :}

A sample solution containing $60 \mu \mathrm{g}$ of Vanadium $(\mathrm{V}), 2.5 \mathrm{ml}$ of $0.2 \%$ reagent of Schiff base solution and $2.0 \mathrm{ml}$ of the buffer solution was added to adjust the $\mathrm{pH} 3.0$. The absorbance of the complex elutes with chloroform was measured at wave length range between $370-560 \mathrm{~nm}$. Following curve fig 2. represents the absorption spectra of vanadium (V) complex. The maximum absorption is observed at $400 \mathrm{~nm}$, so absorbance measurements were carried out at 400 nm wave length. 


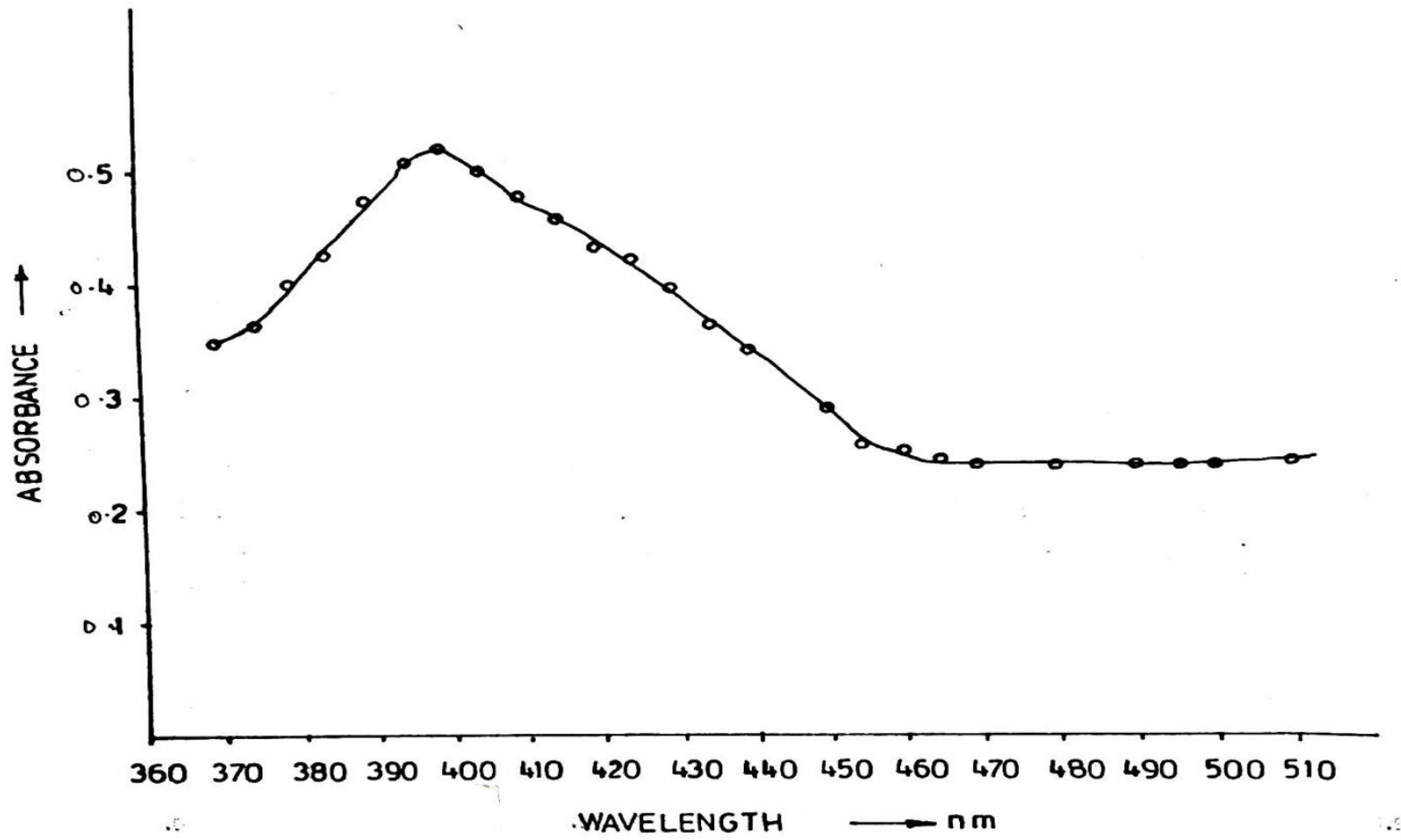

Figure .2 : Absorption Spectra of Vanadium

[VANADIUM (V) :60 $\mu \mathrm{g}, \quad$ pH $: 3.0,0.2 \%$ REAGENT SOLUTION: $2.5 \mathrm{ml}, \quad$ POLYURETHANE FOAM : 7 PIECES, SHAKING TIME :120 sec]

\section{B. EFFECT OF $p H$}

The effect of $\mathrm{Ph}$ on the absorbance of vanadium(V) complex having $60 \mu \mathrm{g}$ vanadium ion in the solution was investigated at $400 \mathrm{~nm}$ in the $\mathrm{pH}$ range 1-10. The maximum and almost constant absorbance was obtained between the pH range 2.0-6.0. So, for all absorbance measurements $\mathrm{pH}$ of solution was taken to be 3.0 shown in fig. 3 and table 1 .

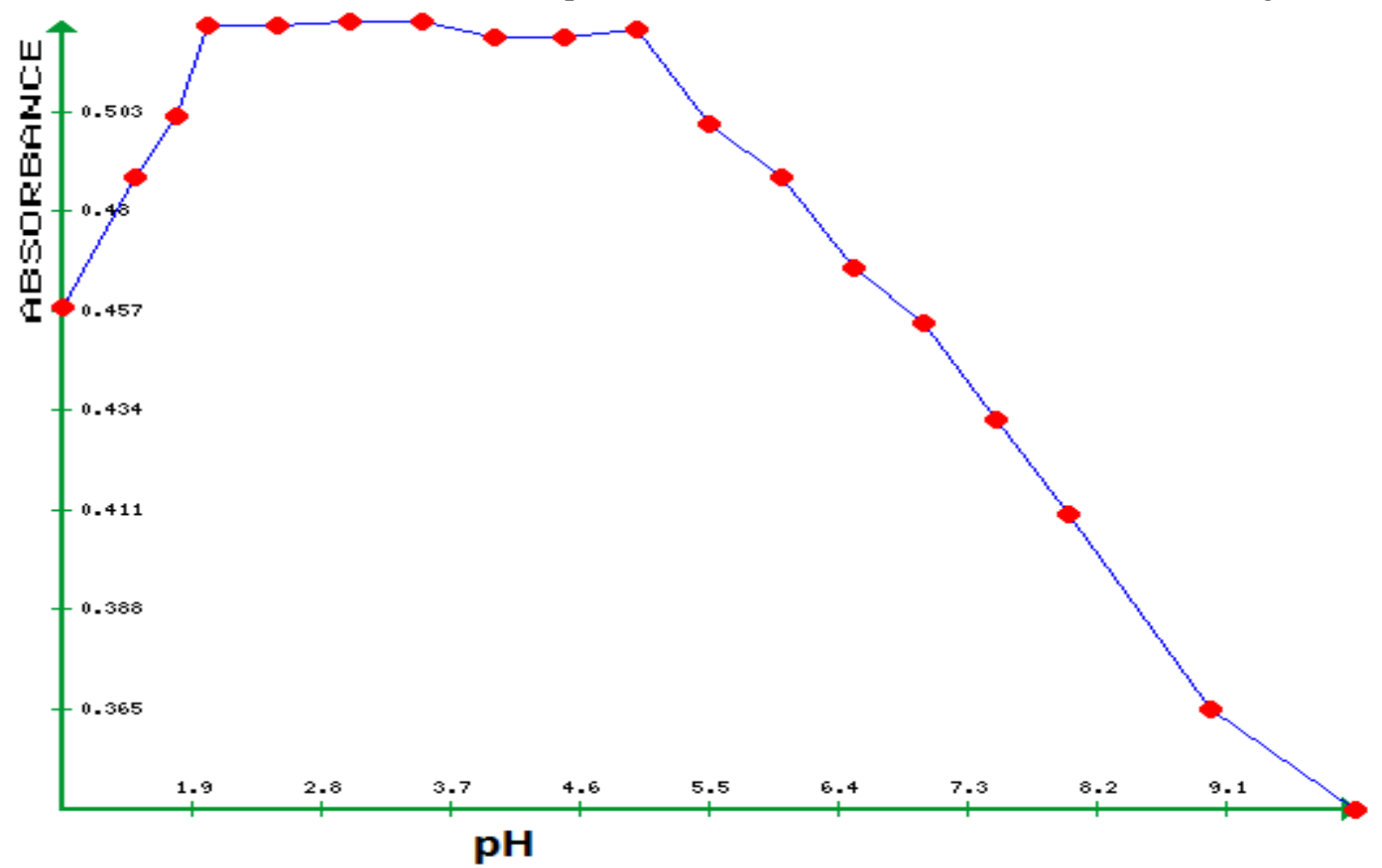

Figure. 3: Effect of pH on absorbance

(VANADIUM (V) : $60 \mu \mathrm{gg}$, WAVELENGTH : $400 \mathrm{~nm}, \quad 0.2 \%$ REAGENT SOLUTION : $2.5 \mathrm{ml}$, POLYURETHANE FOAM : 7 PIECES, SHAKING TIME : 120 sec.)

TABLE (1) : Effect of $\mathrm{pH}$ 


\begin{tabular}{|c|c|}
\hline $\mathrm{pH}$ & Absorbance at $400 \mathrm{~nm}$ \\
\hline 1.0 & 0.458 \\
\hline 1.5 & 0.488 \\
\hline 1.8 & 0.502 \\
\hline 2.0 & 0.523 \\
\hline 2.5 & 0.523 \\
\hline 3.0 & 0.524 \\
\hline 3.5 & 0.524 \\
\hline 4.0 & 0.520 \\
\hline 4.5 & 0.523 \\
\hline 5.0 & 0.522 \\
\hline 5.5 & 0.500 \\
\hline 6.0 & 0.488 \\
\hline 6.5 & 0.467 \\
\hline 7.0 & 0.454 \\
\hline 7.5 & 0.432 \\
\hline 8.0 & 0.410 \\
\hline 8.5 & 0.389 \\
\hline 9.0 & 0.365 \\
\hline 10.0 & 0.342 \\
\hline \multicolumn{2}{|c|}{ Vanadium $(\mathrm{V}): 60 \mu \mathrm{G}$} \\
\hline \multicolumn{2}{|c|}{$0.2 \%$ Reagent : $2.5 \mathrm{ml}$} \\
\hline \multicolumn{2}{|c|}{ Polyurethane foam : 7 pieces } \\
\hline & \\
\hline
\end{tabular}

\section{EFFECT OF REAGENT SOLUTION :}

Different amounts of the reagent solution were prepared for the investigation of the effect of the reagent concentration on the absorbance of vanadium (v) complex. It was prepared by the sample solution containing $60 \mu \mathrm{g}$ of vanadium (v). It was observed at $\mathrm{pH} 3.0$. Almost same absorbance was obtained when 1.5 to $6.0 \mathrm{ml}$ of reagent solution were added therefore, $2.5 \mathrm{ml}$ of reagent solution was considered the suitable quantity to be used for all absorbance measurements as shown in fig. 4 and table 2. 


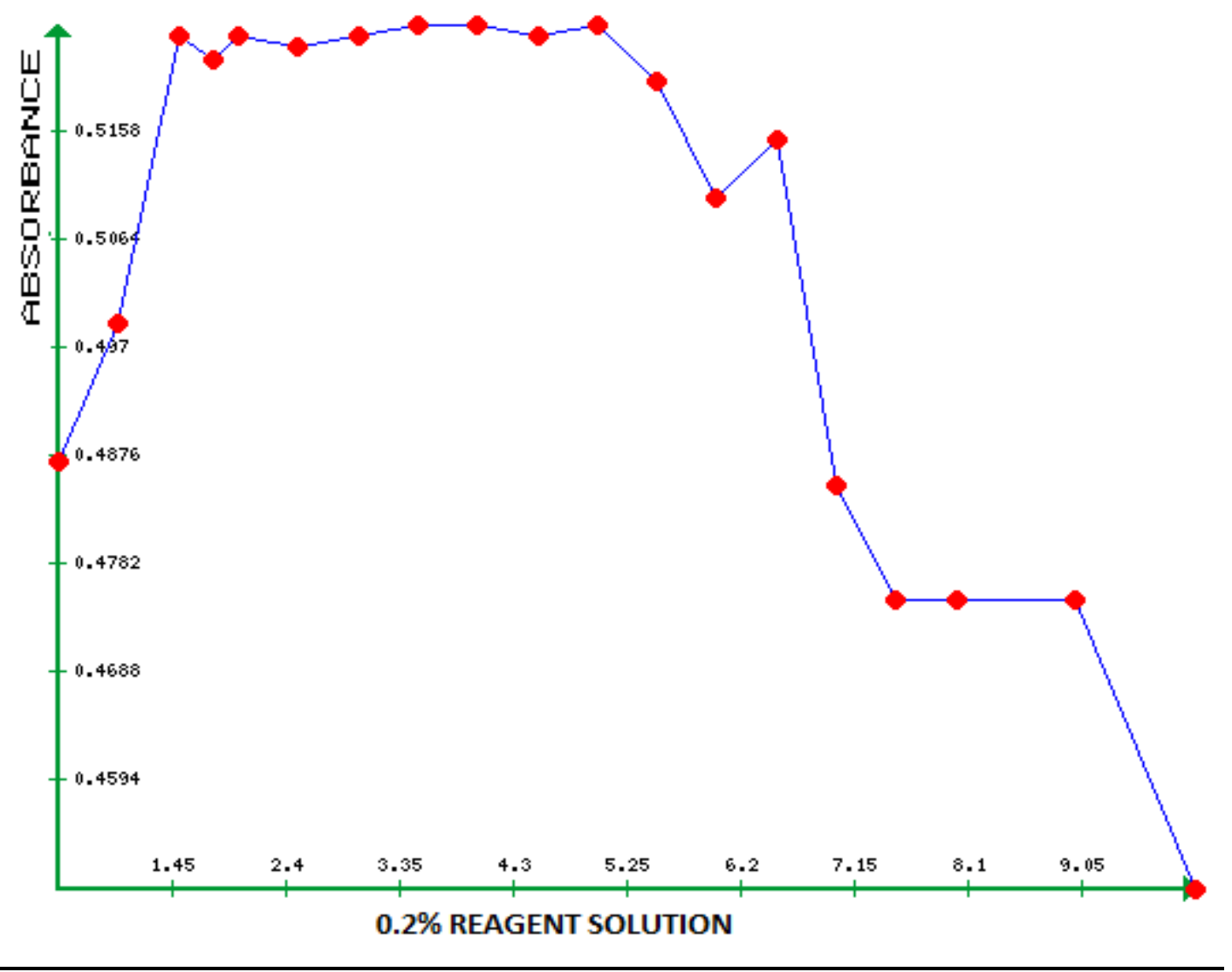

Figure. 4: Effect of Reagent

[VANADIUM (V) :60 $\mu \mathrm{g}$, WAVELENGTH : 400 nm, pH : 3.0, POLYURETHANE FOAM : 7 PIECES, SHAKING TIME :120 sec]

\section{TABLE (2) : Effect of Reagent Concentration}

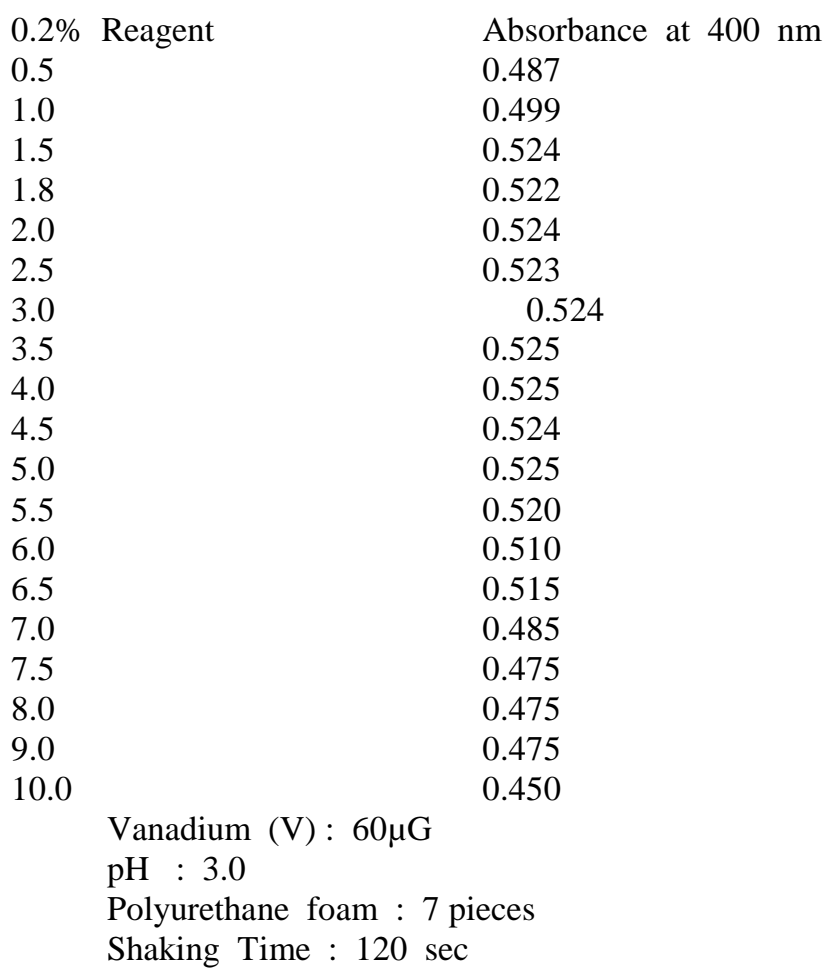




\section{EFFECT OF ADSORBENT :}

This effect was determined by adding different number of prepared polyurethane foam pieces in the vanadium (v) complex solution. The absorbance increased with the addition of 1-3 polyurethane pieces. The value of absorbance was found almost constant upto 9.0 therefore seven foam pieces were taken for all absorbance measurements( Fig. 5 and table 3.)

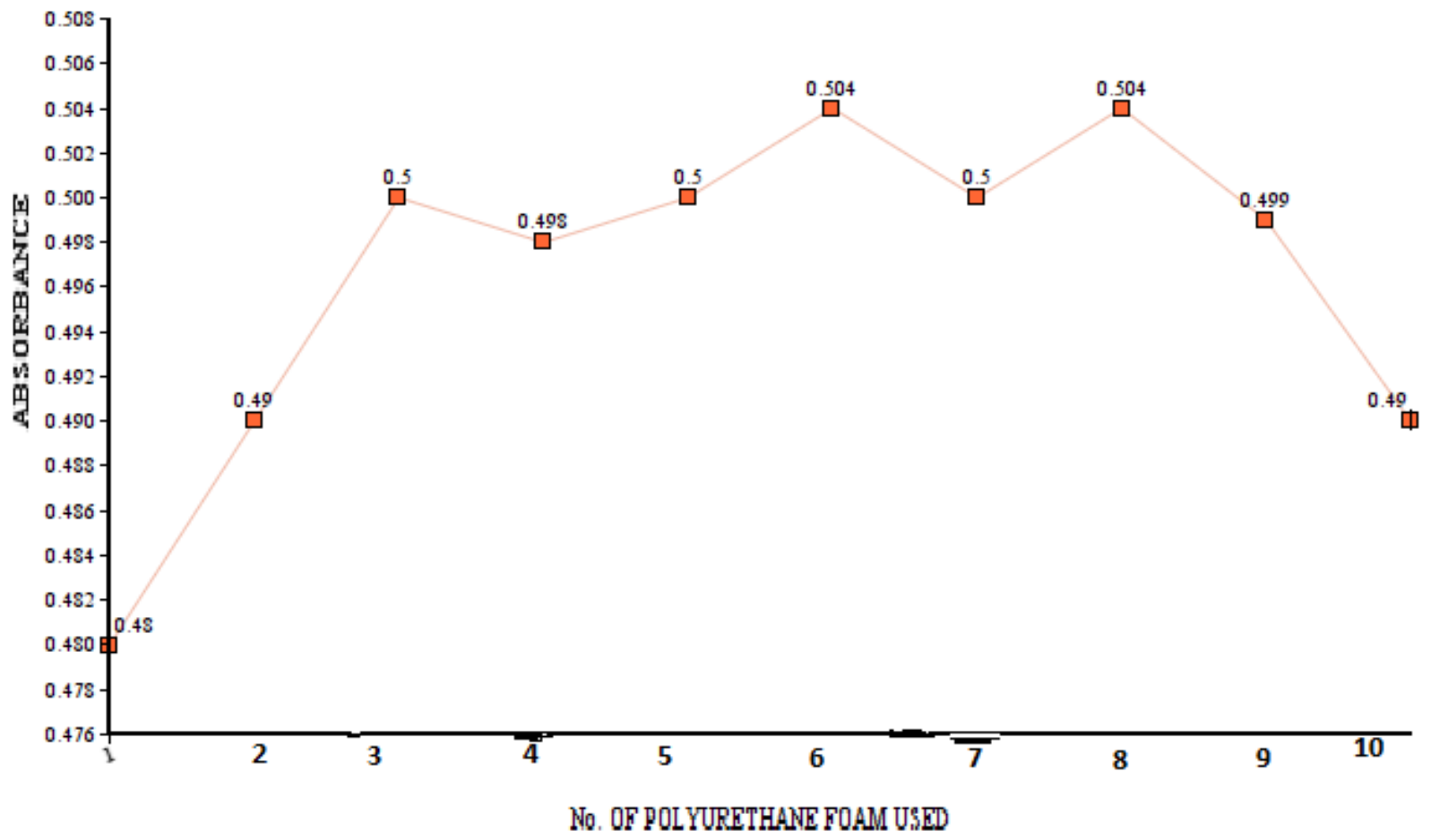

Figure. 5: Effect of Adsorbant

[VANADIUM (V) : $60 \mu \mathrm{g}$, WAVELENGTH $: 400 \mathrm{~nm}, \mathrm{pH}: 3.0,0.2 \%$ REAGENT SOLUTION : $2.5 \mathrm{ml}$, SHAKING TIME : $120 \mathrm{sec}]$

\section{TABLE (3) : Effect of Adsorbent}

$\begin{array}{lc}\begin{array}{l}\text { No. of Polyurethane foam } \\ \text { Pieces used }\end{array} & \text { Absorbance at } 400 \mathrm{~nm} \\ 1 & 0.480 \\ 2 & 0.490 \\ 3 & 0.500 \\ 4 & 0.498 \\ 5 & 0.500 \\ 6 & 0.504 \\ 7 & 0.500 \\ 8 & 0.504 \\ 9 & 0.499 \\ 10 & 0.490 \\ & \\ \text { Vanadium (V) : } 60 \mu \mathrm{G} & \\ \text { pH : 3.0 } & \\ \text { 0.2\% Reagent : } 2.5 \mathrm{ml} & \\ \text { Shaking Time : } 120 \mathrm{sec} & \end{array}$

E. EFFECT OF SHAKING TIME :

Vanadium (v) solution containing $60 \mu \mathrm{g}$ of vanadium on was allowed to satnd in contact with schiff base solution for two minutes. Then the complex was shaken from 5-300 seconds. Absorbance first increased, attained maximum and 
became constant from 20 to 160 seconds. So, 120 second was chosen the shaking time for all absorbance measurements as in fig. 6 and table 4.

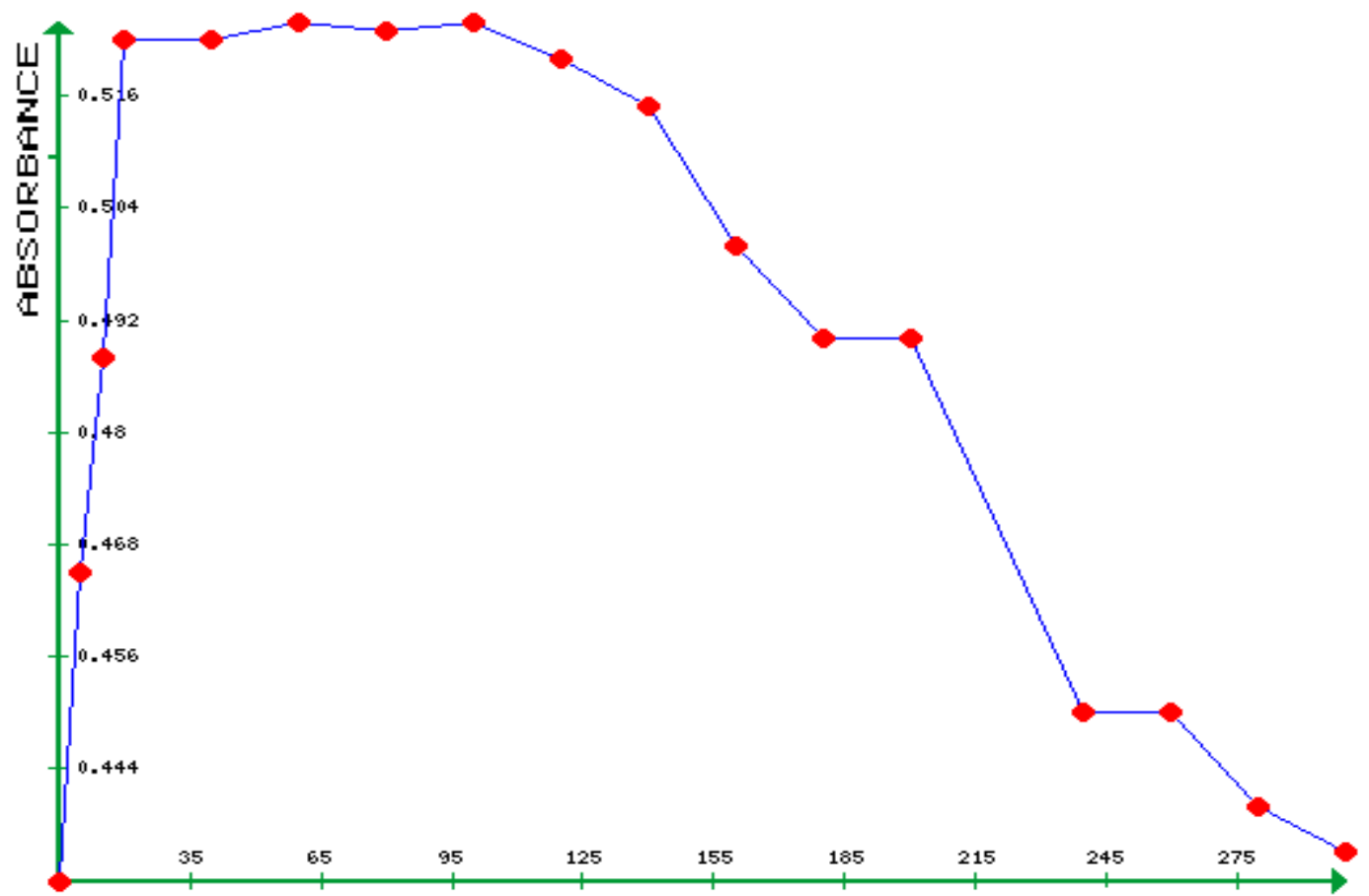

SHAKING TIME in sec

\section{Figure. 6: Effect of Shaking Time \\ [VANADIUM (V) : $60 \mu \mathrm{g}$, WAVELENGTH $: 400 \mathrm{~nm}, \mathrm{pH}: 3.0,0.2 \%$ REAGENT SOLUTION : $2.5 \mathrm{ml}$, POLYURETHANE FOAM : 7 PIECES]}

TABLE (4) : Effect of Shaking Time

Shaking Time (sec.)

5

10

15

20

40

60

80

100

120

140

160

180

200

240

260

280

300
Absorbance at $400 \mathrm{~nm}$

0.432

0.465

0.488

0.522

0.522

0.524

0.523

0.524

0.520

0.515

0.500

0.490

0.490

0.450

0.450

0.440

0.435

Vanadium (V) : $60 \mu \mathrm{G}$

$\mathrm{pH}: 3.0$

Polyurethane foam : 7 pieces

$0.2 \%$ Reagent : $2.5 \mathrm{ml}$

F. CALIBRATION CURVE FOR VANADIUM (V) :

Calibration curve was obtained by the recommended procedure under the optimum condition according to Fig. 7. Beer's law was obeyed in the range 5-90 $\mu \mathrm{g}$. The molar absorptivity was found to be $2.310 \times 10^{4} \mathrm{Lmol}^{-1} \mathrm{~cm}^{-1}$ at $400 \mathrm{~nm}$ and sensitivity being $1.58 \times 10^{-2} \mu \mathrm{g} \mathrm{cm}^{-2}$ of vanadium (v) for the absorbance of 0.001.(Table 5)

This publication is licensed under Creative Commons Attribution CC BY. 


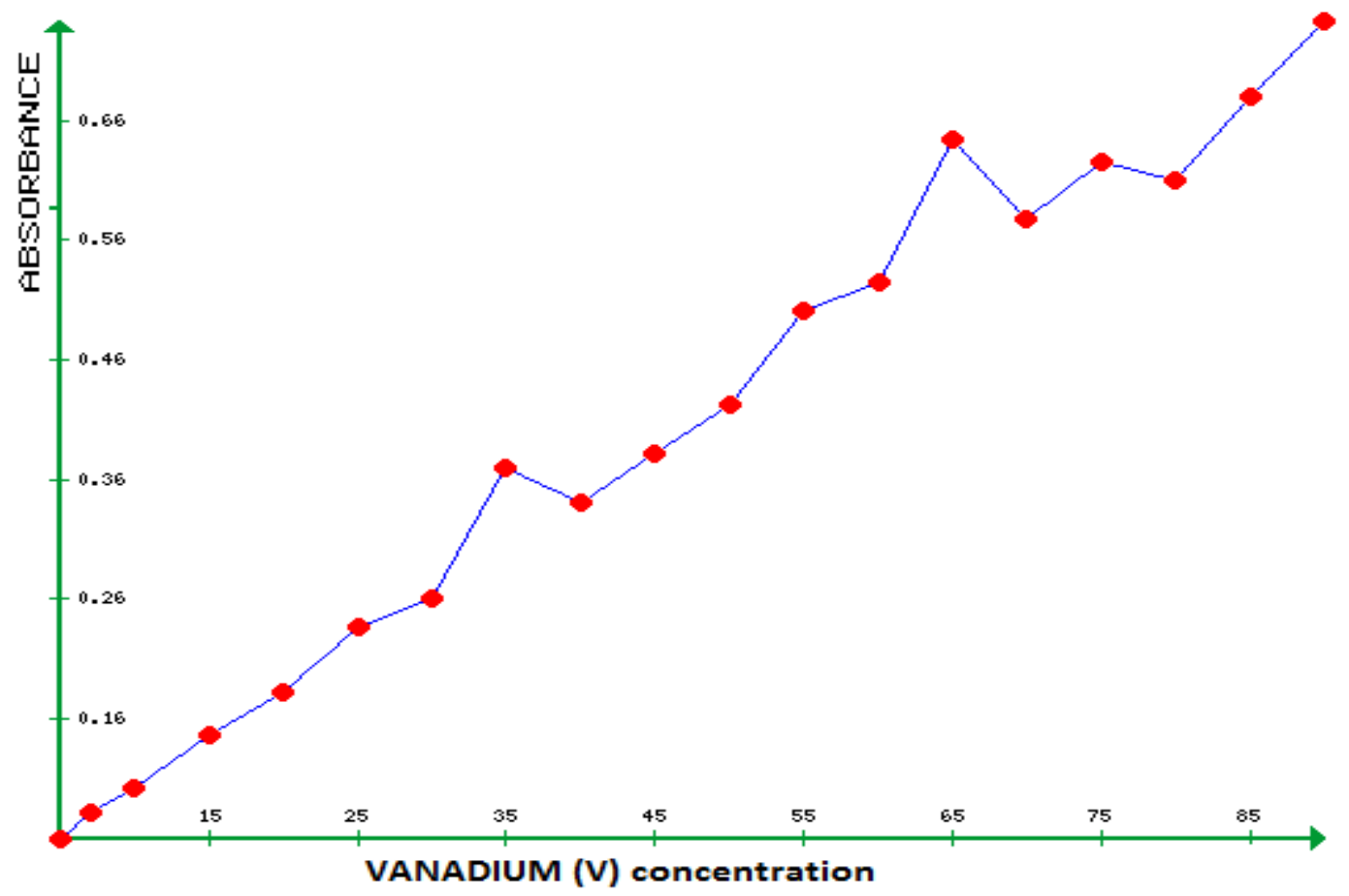

Figure. 7: Calibration Curve of Vanadium

[WAVELENGTH : $400 \mathrm{~nm}, \quad$ pH : 3.0, $0.2 \%$ REAGENT SOLUTION : $2.5 \mathrm{ml}, \quad$ POLYURETHANE FOAM : 7 PIECES]

TABLE (5) : Calibration Data for Vanadium (V)

Vanadium (V) Concentration Absorbance at $400 \mathrm{~nm}$

5

7

10

15

20

25

30

35

40

45

50

55

60

65

70

75

80

85

90
0.060

0.082

0.101

0.146

0.182

0.236

0.261

0.369

0.341

0.382

0.423

0.501

0.524

0.644

0.577

0.625

0.610

0.680

0.742

$\mathrm{pH}: 3.0$

$0.2 \%$ Reagent : $2.5 \mathrm{ml}$

Polyurethane foam : 7 pieces

Shaking Time : $120 \mathrm{sec}$

\section{G. EFFECT OF DIVERSE IONS :}

Interference due to the presence of various amounts of alkali metal salts and metal ions on the absorbance was studied according to the table 6 and 7. 
TABLE (6) : Effect of Diverse Alkali Metal Ion Salts

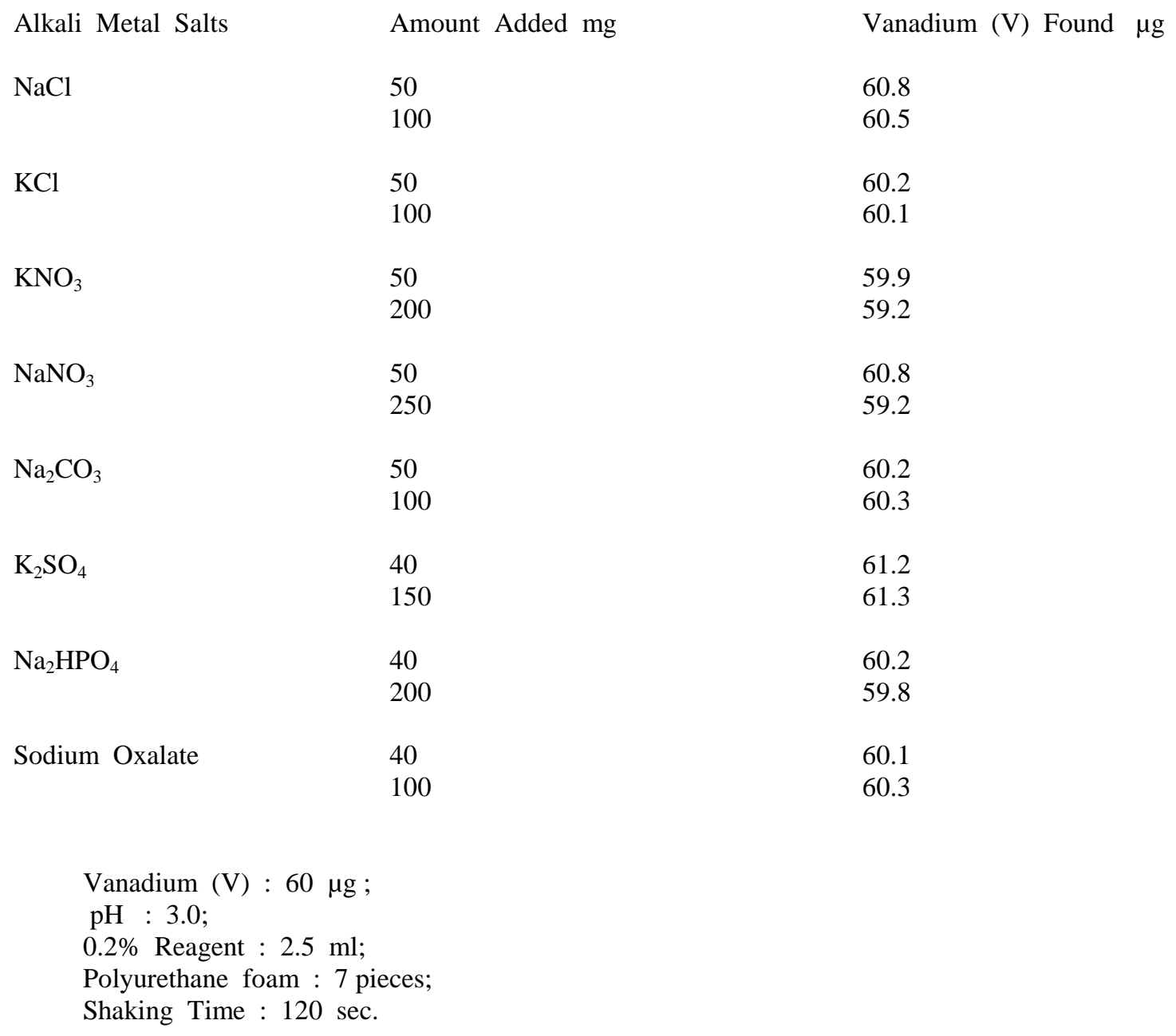

TABLE (7) : Effect of Diverse Metal Ions

$\begin{array}{lll}\text { Diverse Metal Ions } & \text { Amount of Ion Added (mg) } & \text { Vanadium (V) Found } \mu \mathrm{g} \\ & & \\ \text { Co (II) } & 40 & 61.2 \\ & 120 & 62.3 \\ \text { Zn (II) } & 30 & 61.0 \\ & 80 & 60.9 \\ \text { Pd (II) } & 100 & 60.1 \\ & 150 & 61.6 \\ \text { Mn (II) } & 50 & 60.9 \\ & 150 & 59.8 \\ \mathrm{Cu} \text { (II) } & 40 & 59.2 \\ & 200 & 58.6 \\ \mathrm{Mg} \text { (II) } & 100 & 59.3 \\ & 250 & 60.1\end{array}$




$\begin{array}{lll}\text { Sn (II) } & 50 & 60.0 \\ & 100 & 59.9 \\ \mathrm{Fe} \text { (III) } & 50 & 60.2 \\ & 100 & 60.0 \\ \mathrm{Cr} \text { (III) } & & \\ & 100 & 60.0 \\ \mathrm{Al} \text { (III) } & 200 & 59.9 \\ & 40 & 59.8 \\ \mathrm{Bi} \text { (III) } & 100 & 58.6 \\ & & \\ & 30 & 59.2 \\ & 60 & 60.6\end{array}$

Vanadium (V) : $60 \mu \mathrm{g}$;

$\mathrm{pH}: 3.0$;

$0.2 \%$ Reagent : $2.5 \mathrm{ml}$;

Polyurethane foam : 7 pieces;

\section{PRECISION}

Ten examples of the arrangement containing $60 \mu \mathrm{g}$ of vanadium (v) were set up by weakening the stock arrangement and the complex shaped with the reagent was gotten. The absorbance was estimated at $400 \mathrm{~nm}$. Mean absorbance of 0.524 with a standard deviation of $0.28 \%$ was acquired.

\section{CONCLUSION}

In this examination, Schiff base ligand and its complex with vanadium(v) particle were researched. It is found from the above conversation that Schiff base got from pyridine-2carboxaldehyde and 2- amino pyridine is a decent touchy reagent for the spectrophotometric assurance of vanadium(v) particle by the methods for different parameters like $\mathrm{pH}$, reagent focus, adsorbent, shaking time, assorted particle expansion. It likewise can be acceptable applied for the assurance of vanadium(v) in pharmaceutical samples.

\section{ACKNOWLEDGEMENT}

The authors are highly thankful to the CSIR-HRDG, Delhi for funding us in this project work under CSIR-UGC NET-JRF scheme.

\section{REFERENCES}

[1] Troutman H.D. and Long L.M. ; The Synthesis of 2,3- disubstituted-4thiazolidones, J. Am. Chem. Soc., 70, 3436, (1948)

[2] Doergee R.F.; Wilson and Gisroldi Text Book of Organic Medicinal and Pharmaceutical Chemistry, 8th Ed. J.B. Liooincolt Company, 225, (1982)

This publication is licensed under Creative Commons Attribution CC BY.
[3] Juneja H.D. , Munshi K.N. ; Synthetic \& Structural Studies on Coordination Polymers of Mn (II), Co (II), Ni (II), Cu (II) \& $\mathrm{Zn}$ (II) with Azelaic Acid bis-(phenyl hydrazide) \& Azelaic Acid-bis-(2,4dinitrophenyl hydrazide) ; J. Ind. Chem. ;26A, 257, 708 ; (1987)

[4] Maurya P.L., Agarwal B.V. and Dey A.K. ; Inner Complexes of Co (II), Ni(II), Cu (II), Zn(II), Cd (II), Be (II) \& Dioxouranium (VI) with Salicyaldehyde Semicarbazone ; Polymer Bull ; 1, 631 (1979)

[5] Bala M. and Sinha A.I.P. ; Chemistry of Schiff Base ; Asian Journal of Chemistry Reviews , 4, 42, (1993)

[6] Holm R.H., Everett G.W. and Chakravarty A. ; Metal complexes of Schiff bases and $\beta$-ketoamines; Prog. Inorg. Chem. , 7, 83, (1966).

[7] Hobday M.D. and Smith T.D. ; N,N' - ethylenbis(salicylideneiminato) Transition Metal Ion Chelates; Co-ord. chem.. rev. , 9 , 311, (1973).

[8] Akbar Ali M. and Livingstone S.E. ; Metal Complexes of SulphurNitrogen Chelating Agents; Co-ord. chem.Rev., 13, 101, (1974).

[9] Tandon J.P. and Singh R. V. ; S-Benzyldithiocarbazate Schiff Base Complex of Aluminium, Qaurt.Chem.Rev., 1, 88 (1984).

[10] Ahmed H. Orabi ; Extraction of Uranium from Carbonate Solution Using Synthesized Schiff Base and Its Application for Spectrophotometric Determination; Chem. Papers ; 73, 1713-1730 (2019).

[11] Peterburgskii A.V. , Kudryashov V.S. , Tormasava E.E. , Chem. Abstr. 84, 29718K (1976).

[12] Canon H. Alfred, Rose, Geoghem. Environ. , 2, 93 (1977).

[13] Feige F. , "Spot tests in Inorganic Analysis", 5th Ed. , Elsevier, New York, 123 (1970).

[14] Rathore D.P.S. and Tarafder P.K. , Spectrophotometric determination of chromium in geological samples, Analytica Chimica Acta , 257 (1). 129133, (1992).

[15] Pourmohammad M. , Faraji M. and Jafarinejad S. Extraction of chromium(VI) in water sapmples by dispersivr liquid-liquid microextraction based on deep eutectic solvent and determination by Uv-Vis spectrophotometry, Int. J. Env. Analy. Chem. , 1-14, (2019)

[16] Abram E. , Gajdatsy G. , Hermann P., Ujhelyi F. , Borbely J. and Shen J.Z., The colour of monolithic zirconia restorations determined by spectrophotometric examination, Ad. Appl. Cera. , 118(1-2), 3-8 (2019)

[17] Hamon R. F. , Khan A.S. , and Chow A. ; The Cation-Chelation Mechanism of Metal-Ion Sorption by Polyurethanes, Talanta , 29, 313, (1982).

[18] Chow A. , Branagh W. and Chance J. ; Sorption of Organic Dyes by Polyurethane Foam; Talanta, 37 , 407-412 (1990).

[19] Mohammed L.A. , Mahdi N.I. , Aldujaili R.A. ; Preparation , Characterization and The Biological Activity Study of A New 
Heterocyclic (Azo-schiff base) ligand and Their Complexation With \{Co, Ni, Cu, Zn(II) \} Ions ; Egyp. J. Chem. , 63 , 8-9, (2020).

[20] Lather A. , Akhtar S. , Nain S., Agnihotri R. and Agnihotri N. , Spectrophotometric determination of Vanadium(V) in traces using solvent extraction technique, Integ. Res. Adva. , 4(1) , 5-8 (2017)

\section{AUTHORS}

First Author - Dr. Jyoti Sharma, Associate Professor, Raj Rishi Govt. (Autonomous) College, Alwar (Raj.) and sharma_ak002@yahoo.com

Second Author - Sunita (Soni) Tondon, Associate Professor, Raj Rishi Govt. (Autonomous) College, Alwar (Raj.) and 16sunita.tondon@gmail.com.
Third Author - Nidhi Agarwal, Research Scholar, Raj Rishi Bhartrihari Matsya University, Alwar(Raj.) and nidhi.agarwal1210@gmail.com

\section{Address for correspondence}

Nidhi Agarwal

Research Scholar

Dept. Of Chemistry,

Raj Rishi Govt. PG College,

Alwar-301001, Rajasthan, INDIA.

Email: nidhi.agarwal1210@gmail.com ,

Mob. No. -8823947028 